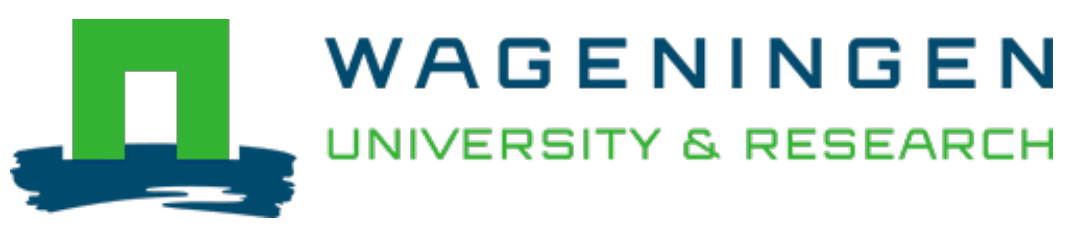

\title{
Calcium promotes formation of large colonies of the cyanobacterium Microcystis by enhancing cell-adhesion
}

\author{
Harmful Algae \\ Chen, Huaimin; Lürling, Miquel \\ https://doi.org/10.1016/j.hal.2020.101768
}

This article is made publicly available in the institutional repository of Wageningen University and Research, under the terms of article $25 \mathrm{fa}$ of the Dutch Copyright Act, also known as the Amendment Taverne. This has been done with explicit consent by the author.

Article 25 fa states that the author of a short scientific work funded either wholly or partially by Dutch public funds is entitled to make that work publicly available for no consideration following a reasonable period of time after the work was first published, provided that clear reference is made to the source of the first publication of the work.

This publication is distributed under The Association of Universities in the Netherlands (VSNU) 'Article $25 \mathrm{fa}$ implementation' project. In this project research outputs of researchers employed by Dutch Universities that comply with the legal requirements of Article $25 \mathrm{fa}$ of the Dutch Copyright Act are distributed online and free of cost or other barriers in institutional repositories. Research outputs are distributed six months after their first online publication in the original published version and with proper attribution to the source of the original publication.

You are permitted to download and use the publication for personal purposes. All rights remain with the author(s) and / or copyright owner(s) of this work. Any use of the publication or parts of it other than authorised under article $25 \mathrm{fa}$ of the Dutch Copyright act is prohibited. Wageningen University \& Research and the author(s) of this publication shall not be held responsible or liable for any damages resulting from your (re)use of this publication.

For questions regarding the public availability of this article please contact openscience.library@wur.nl 


\title{
Calcium promotes formation of large colonies of the cyanobacterium Microcystis by enhancing cell-adhesion
}

\author{
Huaimin Chen $^{\mathrm{a}, \mathrm{b}, *}$, Miquel Lürling ${ }^{\mathrm{b}}$ \\ ${ }^{a}$ College of Environment, Hohai University, No. 1 Xikang Road, Nanjing, 210098, PR China \\ ${ }^{\mathrm{b}}$ Aquatic Ecology \& Water Quality Management Group, Department of Environmental Sciences, Wageningen University, P.O. Box 47, 6700 AA, Wageningen, the \\ Netherlands
}

\section{A R T I C L E I N F O}

\section{Keywords:}

Microcystis

Colony formation

$\mathrm{Ca}^{2+}$

Cell adhesion

Colony morphology

\begin{abstract}
A B S T R A C T
Large Microcystis colonies can lead to the rapid formation of surface accumulations, which are a globally significant environmental issue. Laboratory studies have shown that $\mathrm{Ca}^{2+}$ can quickly promote non-classical Microcystis colony formation via cell-adhesion, but our knowledge of the changes in the morphology of these colonies during subsequent long-term culture with $\mathrm{Ca}^{2+}$ is limited. In this study, a 72-day cultivation experiment was conducted to determine the long-term effects of $\mathrm{Ca}^{2+}$ on Microcystis colony formation. Laboratory results indicate that $\mathrm{Ca}^{2+}$ causes Microcystis to rapidly aggregate and form a colony through cell adhesion, then colony formation by cell-adhesion lost dominance, owing to the decrease in $\mathrm{Ca}^{2+}$ concentrations caused by precipitation/complexation. Although the initial colony morphology by cell adhesion is sparse, the newly divided cells, without separating from the mother cells, constantly fill the gaps in the original colony at $\mathrm{Ca}^{2+}$ concentrations $>40 \mathrm{mg} \mathrm{L}^{-1}$ for a long time, which creates colonies on day 72 with a morphology similar to that of M. ichthyoblabe in Lake Taihu. If the $\mathrm{Ca}^{2+}$ levels in Lake Taihu continue to increase, Microcystis growth rate will decrease only slightly, while the colony proportion of total biovolume and biomass will increase. Moreover, higher $\mathrm{Ca}^{2+}$ concentrations do not affect microcystin content, but promote the content of bound extracellular polysaccharides (bEPS), enabling formation of larger colonies, which may promote Microcystis surface accumulation.
\end{abstract}

\section{Introduction}

Proliferating Microcystis (Cyanobacteria) blooms are an alarming, global, ecological and environmental issue that threaten drinking-water supplies, the fishing industry, aquatic communities, human health and local tourism (de Figueiredo et al., 2004; Paerl and Otten, 2013). Microcystis often exists as large colonies in eutrophic lakes and reservoirs that can resist severe water turbulence and rise to the water surface as a consequence of their increased floating velocity (Kromkamp and Walsby, 1990; Nakamura et al., 1993). Colony formation in Microcystis is considered an advantageous strategy for defence against predators (Cyr and Curtis, 1999; Yang et al., 2009) and help to decrease damage caused by high light intensity (Fujiki and Taguchi, 2002; Wu et al., 2011). Therefore, colony formation plays an important role in the formation of water blooms.

There are two different explanations for the colony formation mechanism: one opinion is that daughter cells fail to separate from mother cells after binary fission (cell division) (Kessel and Eloff, 1975), and the other is that extant single cells or colonies passively aggregate (cell adhesion) (Lürling and Van Donk, 1997). Sato et al. (2016) found that adding $1000 \mathrm{mg} \mathrm{L}^{-1} \mathrm{Ca}^{2+}$ can promote the quick aggregation of single cells into colonies with diameters of up to $20 \mu \mathrm{m}$ after $24 \mathrm{~h}$. However, if an unicellular Microcystis forms the same colony size by cell-division at a high growth rate of 0.6 day $^{-1}$, it still takes 4 days according to the regression of the mean number of cells per colony against mean colony diameter demonstrated by Reynolds and Jaworski (1978). Thus, in theory, unicellular Microcystis can form colonies quicker by cell-adhesion as compared to cell-division.

It is generally accepted that Microcystis form colonies by cell division in a natural environment (Duan et al., 2018; Yang et al., 2008). Recently, Xiao et al. (2017) suggested that cell adhesion effects on colony formation, especially for $M$. wesenbergii, were present in Lake Taihu. Qin et al. (2018) also found that the mean size of Microcystis colonies in Lake Taihu more than doubled within $48 \mathrm{~h}$ during the Typhoon "Soulik" in 2013. This was attributed to the presence of bound extracellular polysaccharides (bEPS), and wind-induced turbulence

\footnotetext{
* Corresponding author at: College of Environment, Hohai University, No. 1 Xikang Road, Nanjing, 210098, PR China.

E-mail address: huaiminchen@163.com (H. Chen).
} 
promoted colony enlargement through the aggregation of small colonies. However, other studies have shown that Microcystis bEPS are negatively charged (Sato et al., 2016, 2017), and therefore, it would be difficult for Microcystis to form large colonies by collision because of electrostatic repulsion. $\mathrm{Ca}^{2+}$ is an important divalent electrolyte cation in water bodies, which coordinates primarily with the negatively charged carboxyl groups of natural organic matter (NOM) (Ahn et al., 2008; Milne et al., 2003). Microcystis bEPSs are a type of NOM and play a pivotal role in colony formation (Xu et al., 2013). Xu et al. (2016) indicated that bEPS extracted from Microcystis in a freshwater lake could aggregate into a large group under a $80 \mathrm{mg} \mathrm{L}^{-1} \mathrm{Ca}^{2+}$ concentration. Moreover, large Microcystis colonies can be formed by cell adhesion under high $\mathrm{Ca}^{2+}$ concentration for a short period (1-8 day) of cultivation in the lab (Wang et al., 2011; Xu et al., 2016; Zhao et al., 2011).

Nevertheless, disentangling the effect of $\mathrm{Ca}^{2+}$ on Microcystis colony formation is still hindered by the fact that the colony morphologies with loosely arranged inner-colony cells under laboratory conditions are markedly different from those observed in freshwater systems (Xiao et al., 2018). Xiao et al. (2018) hypothesized that these non-classical colonies could continue to grow into larger $M$. ichthyoblabe-like colonies with more tightly arranged cells and, then, gradually change into $M$. wesenbergii-like colonies and, subsequently, to M. aeruginosa-like colonies with changing environmental conditions. The culture time in previous studies of $\mathrm{Ca}^{2+}$ inducing Microcystis colony formation was usually less than 2 weeks. Such a short time may not even be enough to achieve the first transition route from non-classical colonies to $M$. ichthyoblabe-like colonies.

In this study, unicellular Microcystis were cultured under different $\mathrm{Ca}^{2+}$ concentrations for up to 72 days to search for large $M$. ichthyoblabe-like colonies. The objectives of this study were 1) to investigate the change of $\mathrm{Ca}^{2+}$ concentration in the long-term process of colony formation; 2) to clarify whether the non-classical colonies could change into $M$. ichthyoblabe-like colonies; 3 ) to explore the effect of continuous $\mathrm{Ca}^{2+}$ increase on Microcystis blooms.

\section{Materials and methods}

\subsection{Microcystis cultivation}

The cyanobacterial strain Microcystis aeruginosa PCC 7820 was obtained from the Aquatic Ecology and Water Quality Management Group laboratory in Wageningen University and cultivated in $300 \mathrm{~mL}$ conical flasks containing $200 \mathrm{~mL}$ sterilised BG-11 medium $(\mathrm{pH}=7)$ for the subsequent batch experiments (Allen, 1968). Total N and P in the BG-11 medium were adjusted to $10 \mathrm{mg} \mathrm{L}^{-1}$ and $1 \mathrm{mg} \mathrm{L}^{-1}$, respectively. The initial M. aeruginosa PCC 7820 were single cells. After autoclaving all utensils and medium, the single Microcystis were batch-cultured into $300 \mathrm{~mL}$ conical flasks containing $200 \mathrm{~mL}$ modified medium with different $\mathrm{Ca}^{2+}$ concentrations (20,40,60, 80, and $100 \mathrm{mg} \mathrm{L}^{-1}$ ), using a $\mathrm{CaCl}_{2}$ solution with three replicates for each treatment. All cultures were kept at $20^{\circ} \mathrm{C}$ with a light intensity of $30 \mu \mathrm{mol} \mathrm{m}^{-2} \mathrm{~s}^{-1}$ under a 12 $\mathrm{h}: 12 \mathrm{~h} \mathrm{light/dark}$ cycle. The flasks were shaken by hand thrice per day to prevent the cells from adhering to the inner walls of the flasks. Due to nutrient limitation, $5 \mathrm{ml}$ algae from each flask was transferred into a new flask containing the corresponding medium on day 36 and gently shaken. Then, the initial cell densities of day 0 and 36 in all new flasks were measured. The entire experiment lasted 72 days.

\subsection{Determination of colony size and growth rate}

Colony size samples were collected every 12 days from day 0 to 36 and every 18 days from day 36 to 72 . Cell density samples were collected every 3 days from day 0 to 36, and every 6 days from day 36 to 72. Colony pictures were taken by fluorescence microscope at day 72 (Leica Microsystems, Rijswijk, The Netherlands).

\subsubsection{Colony size analysis}

Photographs of the colony size samples were taken using an Olympus C-5050 digital camera (Olympus, Tokyo, Japan) coupled to an Olympus CX31 optical microscope, then used to measure colony size using UTHSCSA ImageTool v3.00 software (Wilcox et al., 2002). The length and width of Microcystis colonies were measured from the longest axis (length) and the shortest axis (width, aligned perpendicularly to the longest axis) and used to calculate the diameter of each Microcystis using the following equation: diameter $=$ (length $\times$ width) $)^{1 / 2}$ (Zhu et al., 2016). Then, the mean colony diameter $\left(D_{50}\right)$ value was used to estimate the average colony size of all measured samples, which indicated that $50 \%$ of the total mass of the particles in the colony were below the average size (Afoakwa et al., 2008; Li et al., 2014). More than 200 colonies per sample were analysed to determine the $\mathrm{D}_{50}$ value.

\subsubsection{Cell counting}

To estimate Microcystis biomass, a $10 \mathrm{~mL}$ centrifuge tube containing $5 \mathrm{~mL}$ of cell density sample was placed in a $100{ }^{\circ} \mathrm{C}$ oscillating water bath at $120 \mathrm{rpm}$; samples were oscillated for approximately $5 \mathrm{~min}$ to completely disperse the colonies into constituent particles (Joung et al., 2006). Joung et al. (2006) indicated that the cell numbers of the $\mathrm{Mi}$ crocystis aeruginosa UTEX 2388 did not significantly decrease after 5min of boiling. Then cell density was counted using a Casy counter (Casy TTC, Schärfe System, GmBh, Reutlingen, Germany) after dilution to an appropriate concentration $\left(<2 \times 10^{4}\right.$ cells $\left.\mathrm{mL}^{-1}\right)$. The mean growth rates $(\mu)$ were calculated using the following formula:

$\mu=\frac{\ln C_{t_{1}}-\ln C_{t}}{t_{1}-t}$

where $\mathrm{C}_{\mathrm{t}}$ and $\mathrm{C}_{\mathrm{t} 1}$ are the cell densities at time $\mathrm{t}$ and the next time $\mathrm{t}_{1}$, respectively.

\section{3. bEPS and microcystin analysis}

The bEPS of $5 \mathrm{~mL}$ algae samples on day 36 were extracted as described by Li et al. (2013a) and analysed by the phenol-sulfuric acid method (Dubois et al., 1956) using glucose as a standard. Finally, the bEPS content was normalised by the cell counts. Meanwhile, $18 \mathrm{~mL}$ algae samples in each flask were filtered over a glass-fibre filter (Whatman GF/C) for microcystin analysis. Contents of eight MC variants (dm-7-MC-LR, MC-LR, MC-LY, MC-LW, MC-LF, dm-7-MC-RR, MCRR and MC-YR) were extracted and measured by LC-MS/MS as described by Lurling et al. (2017).

\subsection{Secondary PCC 7820 incubation}

To explore the changes of $\mathrm{Ca}^{2+}$ concentrations in the process of colony formation, the secondary PCC 7820 incubation under a $\mathrm{Ca}^{2+}$ concentration of $80 \mathrm{mg} \mathrm{L}^{-1}$ with three replicates was conducted for 35 days. The BG-11 concentration and culture conditions were the same as those described in section 2.2.1. Samples were collected every 7 days to measure $\mathrm{pH}$, dissolved inorganic carbon (DIC), $\mathrm{Ca}^{2+}$ concentration and cell density. Before determining cell density, the colonies in the samples were dissociated into single cells following the methods described in 2.2.2. Then, cells were placed in a haemocytometer counting chamber and counted at least thrice using an optical microscope (Olympus CX31; Olympus, Tokyo, Japan) at 400X magnification. If the difference between the results was less than $10 \%$, the mean of the three results was used as the final biomass. Otherwise, additional counting was performed.

The $\mathrm{pH}$ was determined using a compact $\mathrm{pH}$ meter ( $\mathrm{pH}$ Testr30, Eutech, CA, USA). Then, the samples were filtered through a $0.45 \mu \mathrm{m}$ porosity membrane and analysed for $\mathrm{Ca}^{2+}$ and DIC. $\mathrm{Ca}^{2+}$ and DIC concentrations were measured by inductively coupled plasma optical emission spectroscopy (ICP-OES Optima-2000, Perkin Elmer, MA, USA) 
and a total organic carbon analyser (TOC, Shimadzu, Kyoto, Japan), respectively. Inasmuch as $\mathrm{pH}$ and chemical composition of the medium might influence the $\mathrm{Ca}^{2+}$ concentration, chemical equilibrium modelling was applied using the program CHEAQS Next (version P2019.2) (Verweij, 2019) to estimate the $\mathrm{Ca}^{2+}$ concentration. To this end, $\mathrm{H}^{+}$ activity from measured $\mathrm{pH}$, ions as added with the BG11 stocks and citric acid as potential organic complexation (model 7, Tipping 2011) were included.

\subsection{Calculations and statistical analysis}

\subsubsection{Colony formation mechanism determination}

The fold-increase value of cells per colony $(\mathrm{f}-\mathrm{CC}$ ) divided by the fold-increase value of total biomass (f-B) was used to differentiate between colony formation dominated by cell-adhesion or cell-division (Xiao et al., 2017). If $\mathrm{f}-\mathrm{CC} / \mathrm{f}-\mathrm{B}$ was greater than 1 , colony formation was induced by cell-adhesion; otherwise, it was induced by cell-division. To clarify the colony formation mechanism in different periods under the effects of $\mathrm{Ca}^{2+}$, the whole culture period was divided into five parts: days $0-12$, days $12-24$, days $24-36$, days $36-54$, and days 54-72. Then, the f-B value of each part was calculated using the following equation:

$\mathrm{f}-\mathrm{B}=\mathrm{C}_{\mathrm{t} 1} / \mathrm{C}_{\mathrm{t}}$

where $C_{t}$ and $C_{t 1}$ are cell densities at begin time $t$ and the end time $t_{1}$ of each part. The $\mathrm{f}-\mathrm{CC}$ value of each part was determined using the following equation:

$\mathrm{f}-\mathrm{CC}=\mathrm{N}_{\mathrm{t} 1} / \mathrm{N}_{\mathrm{t}}$

where $\mathrm{N}_{\mathrm{t}}$ and $\mathrm{N}_{\mathrm{t} 1}$ are the number of cells per colony at begin time $\mathrm{t}$ and the end time $t_{1}$ of each part. Furthermore, $\mathrm{N}$ was computed from the colony diameter as shown below (Reynolds and Jaworski, 1978):

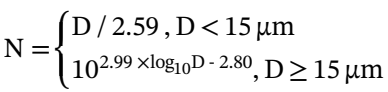

where $\mathrm{D}$ is the colony diameter $(\mu \mathrm{m}), 2.99$ and 2.80 are constants, and 2.59 is the average diameter of $M$. aeruginosa single cells computed from the range of $2.38-2.81 \mu \mathrm{m}$ provided by Reynolds (2006). In this study, $\mathrm{D}_{50}$ was used to calculate $\mathrm{N}$.

\subsubsection{Statistical analyses}

The experimental laboratory data were presented as the mean $\pm \mathrm{SD}$, and the differences between treatments were analysed by ANOVA using Tukey's post-hoc test. Statistical analyses were performed using SPSS 19.0 software (IBM, Armonk, NY, USA). For all analyses, a p-value < 0.05 was considered statistically significant.

\section{Results}

\subsection{Changes in $\mathrm{pH}, \mathrm{DIC}$, and $\mathrm{Ca}^{2+}$ concentration during the secondary PCC 7820 incubation}

During the secondary PCC 7820 incubation with a $\mathrm{Ca}^{2+}$ concentration of $80 \mathrm{mg} \mathrm{L}^{-1}$, the $\mathrm{pH}$, DIC, and cell density increased over time (Fig. 1). The DIC increased from day 0 to 28 and then decreased after day 28. The decreased rate of $\mathrm{Ca}^{2+}$ from day 0 to 14 was quicker than that from day 14 to 35 . This decrease was not predicted from chemical equilibrium modelling that showed fairly constant $\mathrm{Ca}^{2+}$ concentrations in the first two weeks ( $\mathrm{pH}$ 6.99-8.51) and a decline in the latter period due to elevated pH (Fig. 2).

\subsection{Growth rates, bEPS, and microcystins of Microcystis at different $\mathrm{Ca}^{2+}$} concentrations

The final Microcystis cell density at days 36 and 72 decreased

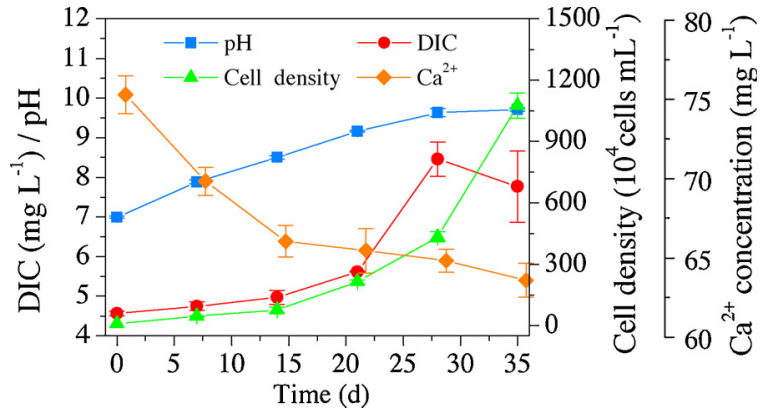

Fig. 1. The changes in $\mathrm{pH}$, DIC, cell density, and $\mathrm{Ca}^{2+}$ concentration in the secondary PCC 7820 incubation. Error bars represent the SD of triplicate samples.

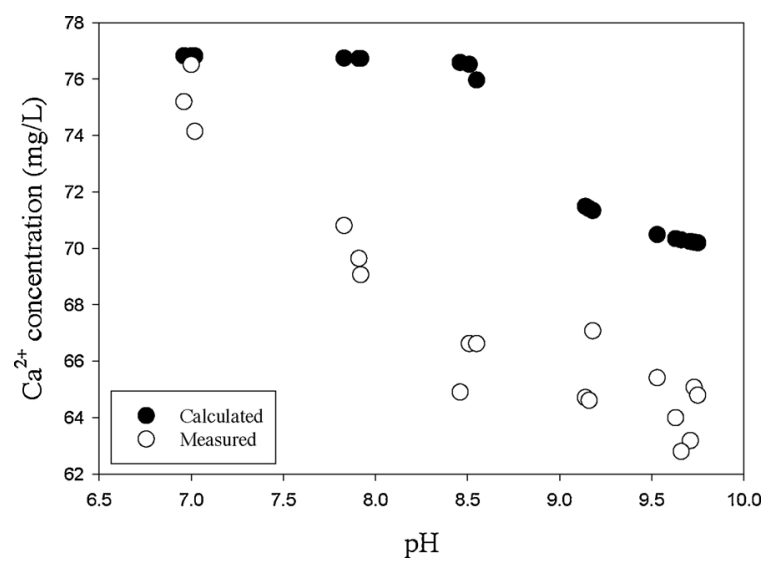

Fig. 2. Measured $\mathrm{Ca}^{2+}$ concentrations and calculated $\mathrm{Ca}^{2+}$ concentrations using the model CHEAQS Next at different measured culture pH values.

slightly with increasing $\mathrm{Ca}^{2+}$ concentrations from 20 to $100 \mathrm{mg} \mathrm{L}^{-1}$ (Fig. 3). The mean growth rate at each $\mathrm{Ca}^{2+}$ concentration varied from 0.07 to 0.22 day $^{-1}$ and decreased with time during days $0-36$ and 36-72 (Fig. 4).

bEPS content increased with increased $\mathrm{Ca}^{2+}$ concentration. Moreover, the bEPS in $100 \mathrm{mg} \mathrm{L}^{-1}$ was significantly $(\mathrm{p}<0.05)$ higher than that in $20 \mathrm{mg} \mathrm{L}^{-1}$ (Fig. 5a). However, there were no significant differences in total microcystin content under different $\mathrm{Ca}^{2+}$ concentrations (Fig. 5b).

\subsection{Change in Microcystis colony size at different $\mathrm{Ca}^{2+}$ concentrations}

$\mathrm{Ca}^{2+}$ adsorbed the already existing single cells into the large colonies in a short cultivation time during the first 12 days (Fig. 6, Table 1). Furthermore, higher $\mathrm{Ca}^{2+}$ concentrations led to a larger colony size and higher colonial proportion of total biovolume (Figs. 6 and 7). However, because the growth rate of a colony was lower than that of single cells, the unicellular proportion of the total biovolume all increased from day 12 to 36 under different $\mathrm{Ca}^{2+}$ concentrations (Fig. 7). As shown by the values of $\mathrm{f}-\mathrm{CC} / \mathrm{f}-\mathrm{B}$ in Table 1 , during days 12-36, colony formation was initially dominated by cell-adhesion (days $0-12$ : $\mathrm{f}-\mathrm{CC} / \mathrm{f}-\mathrm{B}>1$ ), but changed into a process dominated by celldivision (days 12-36: $\mathrm{f}-\mathrm{CC} / \mathrm{f}-\mathrm{B}<1$ ). Moreover, $\mathrm{D}_{50}$ values decreased from day 12 to 36 (Fig. 6). When transferred into new medium, from day 36 to 72, the $D_{50}$ continued to increase (Fig. 6). The proportion of single cells as part of the total biovolume on day 54 was lower that on day 36 in all $\mathrm{Ca}^{2+}$ concentrations; large colonies were formed in treatments with $60 \mathrm{mg} \mathrm{Ca}^{2+} \mathrm{mg} \mathrm{L}^{-1}$ or higher (Fig. 7).

The Microcystis pictures from the $100 \mathrm{mg} \mathrm{L}^{-1} \mathrm{Ca}^{2+}$ treatment taken at different times showed that small colonies gradually grew into larger ones (Fig. 8a-e). Fluorescence micrograph indicated that a large colony 

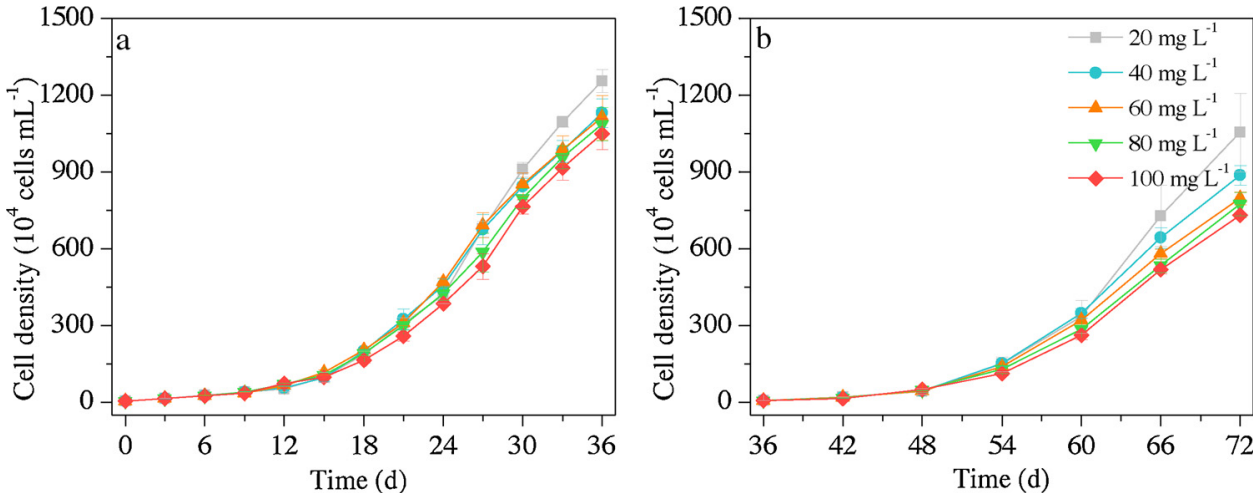

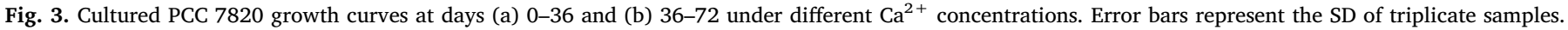

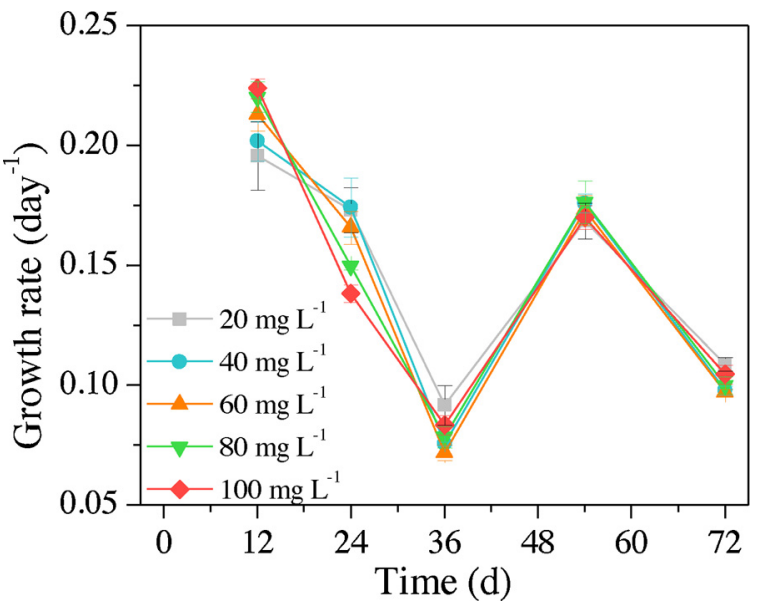

Fig. 4. Temporal variations of mean growth rate of PCC 7820 with different $\mathrm{Ca}^{2+}$ concentrations (mean $\pm \mathrm{SD}$ ).

was formed with numerous living Microcystis cells without other impurities (Fig. 8f). The Microcystis colonies formed at different $\mathrm{Ca}^{2+}$ concentrations (except in $20 \mathrm{mg} \mathrm{L}^{-1}$, Fig. 9a) and present on the last day (day 72) (Fig. 9b-e) were similar morphologically similar to $M$. ichthyoblabe present in Lake Taihu in June 2016 (Fig. 9f).

\section{Discussion}

4.1. The change of $\mathrm{Ca}^{2+}$ concentration in long-term process of colony formation

Our lab results showed that the $\mathrm{Ca}^{2+}$ concentration decreased with increased Microcystis cell density (Fig. 2). Based on previous studies, the mean $\mathrm{Ca}^{2+}$ concentrations inside of Microcystis cell is $4.00 \mathrm{~g} \mathrm{~kg}^{-1} \mathrm{dry}$

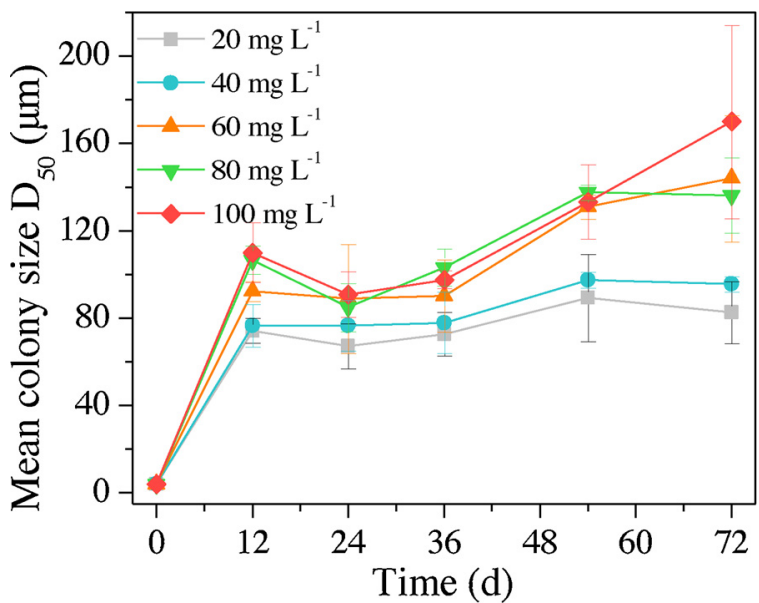

Fig. 6. Changes in cultured mean colony size $\left(\mathrm{D}_{50}\right)$ under different $\mathrm{Ca}^{2+}$ concentrations. Error bars represent the SD of triplicate samples.

Table 1

The temporal variations of $\mathrm{f}-\mathrm{CC} / \mathrm{f}-\mathrm{B}$ over culturing time.

\begin{tabular}{llllll}
\hline $\mathrm{Ca}^{2+}$ & Days 0-12 & Days 12-24 & Days 24-36 & Days 36-54 & Days 54-72 \\
\hline $20 \mathrm{mg} \mathrm{L}^{-1}$ & $\mathbf{5 9 . 5 1}$ & 0.09 & 0.42 & 0.25 & 0.22 \\
$40 \mathrm{mg} \mathrm{L}^{-1}$ & $\mathbf{6 0 . 6 1}$ & 0.12 & 0.43 & 0.24 & 0.29 \\
$60 \mathrm{mg} \mathrm{L}^{-1}$ & $\mathbf{9 2 . 7 2}$ & 0.12 & 0.44 & 0.38 & 0.41 \\
$80 \mathrm{mg} \mathrm{L}^{-1}$ & $\mathbf{1 3 0 . 5 8}$ & 0.08 & 0.70 & 0.28 & 0.29 \\
$100 \mathrm{mg} \mathrm{L}^{-1}$ & $\mathbf{1 3 7 . 2 3}$ & 0.11 & 0.45 & 0.33 & 0.59 \\
\hline
\end{tabular}

weight (Krivtsov et al., 2005). The mean diameter and density of single Microcystis are $2.59 \mu \mathrm{m}$ (Reynolds and Jaworski, 1978) and $985 \mathrm{~kg} \mathrm{~m}^{-3}$ (Li et al., 2016). The calculated $\mathrm{Ca}^{2+}$ content in a single cell is then about $0.06 \mathrm{pg}$ cell $^{-1}$. In this study, the cell density is up to $1075 \times 10^{4}$
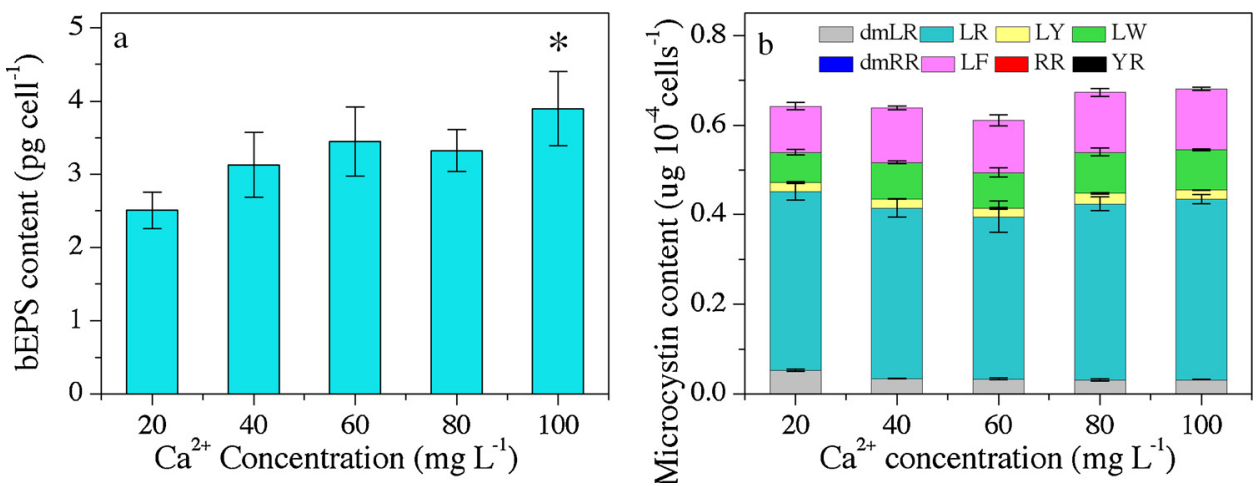

Fig. 5. (a) bEPS and (b) concentrations of different microcystin (MC) variants under different $\mathrm{Ca}^{2+}$ concentrations. 


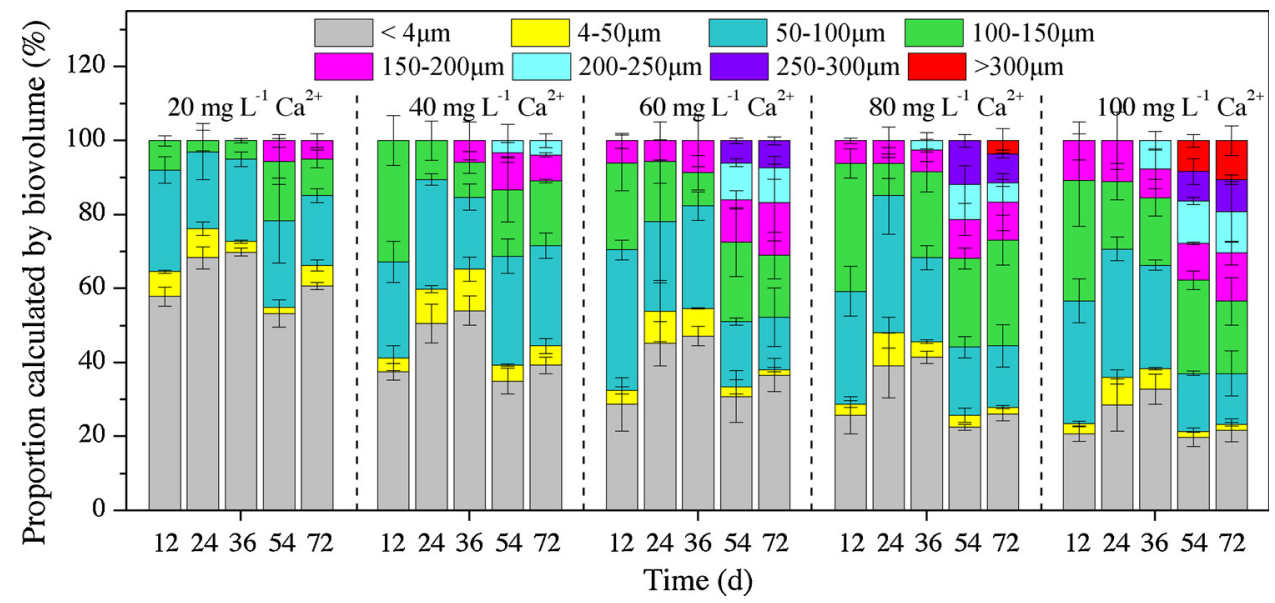

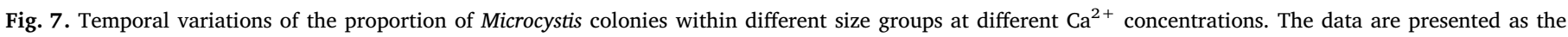
mean $\pm \mathrm{SD}$

cells $\mathrm{mL}^{-1}$ in the secondary PCC 7820 incubation (Fig. 1). Therefore, the $\mathrm{Ca}^{2+}$ consumed by Microcystis is only $0.51 \mathrm{mg} \mathrm{L}^{-1}$, which is $4.25 \%$ of the reduction of $\mathrm{Ca}^{2+}$ concentration $\left(12 \mathrm{mg} \mathrm{L}^{-1}\right)$.

Microcystis possesses a calcification potential, which means that due to photosynthetic uptake of inorganic carbon the $\mathrm{pH}$ adjacent to cyanobacterial cells can rise promoting $\mathrm{CaCO}_{3}$ precipitation (Riding, 2006). Our lab results showed the $\mathrm{pH}$ increased with the increase of Microcystis cell density. The DIC increased from day 0 to 28 and then decreased after day 28 in the lab assay (Fig. 1). The measured reduction of $\mathrm{Ca}^{2+}$ concentration in the lab-assay is of similar magnitude to the results of Li et al. (2017). They cultured Microcystis under a $\mathrm{Ca}^{2+}$ concentration of $200 \mathrm{mg} \mathrm{L}^{-1}$ and found that $\mathrm{Ca}^{2+}$ was reduced by 20 $\mathrm{mg} \mathrm{L}^{-1}$ when the $\mathrm{pH}$ increased from 7.6 to 9.6. Although a decrease of $\mathrm{Ca}^{2+}$ concentration could be caused by Microcystis calcification, chemical equilibrium modelling revealed this could not explain all of the decline (Fig. 2). Especially the fast initial drop seems not in line with $\mathrm{pH}$ driven $\mathrm{Ca}^{2+}$ precipitation (see Fig. 1). Since $\mathrm{Ca}^{2+}$ is essential in cyanobacterial photosynthesis (Becker and Brand, 1982), some uptake by cells is to be expected. In addition, Microcystis secretes large amounts of fibrous exopolysaccharides in which a calcium-binding protein is involved (Harel et al., 2012). In this exopolysaccharide environment calcium binding takes place (Jansson and Northen, 2010), calcium complexation has been well-documented (e.g. Bazin et al. (1995)).

\subsection{The effect of $\mathrm{Ca}^{2+}$ on changes in the morphology of Microcystis colonies}

It is a bizarre phenomenon that Microcystis colonies collected from lakes often change into single cells after some generations under axenic laboratory conditions (Bolch and Blackburn, 1996; Reynolds et al., 1981; Yang et al., 2006). This may be because the $\mathrm{Ca}^{2+}$ concentration in the BG-11 medium ( $\sim 10 \mathrm{mg} \mathrm{L}{ }^{-1}$ ) (Stanier et al., 1971) is much lower than that in some lakes ( $>30 \mathrm{mg} \mathrm{L}^{-1}$ ), where Microcystis spp. predominated in the plankton, such as Rewalsar Lake (Gaury et al., 2018; Jindal et al., 2014), Lake Kinneret (Sea of Galilee) in Israel (Hadas et al., 2015; Katz and Nishri, 2013) and Lake Donting in China (Chen et al., 2018; Wang et al., 2018b). Li et al. (2013b) found that wild M. ichthyoblabe soaked in deionised water in the dark at $4{ }^{\circ} \mathrm{C}$ gradually dissociated into small loose colonies or even single cells, but those soaked in $20 \mathrm{mg} \mathrm{L}^{-1} \mathrm{Ca}^{2+}$ solution could maintain their morphology,
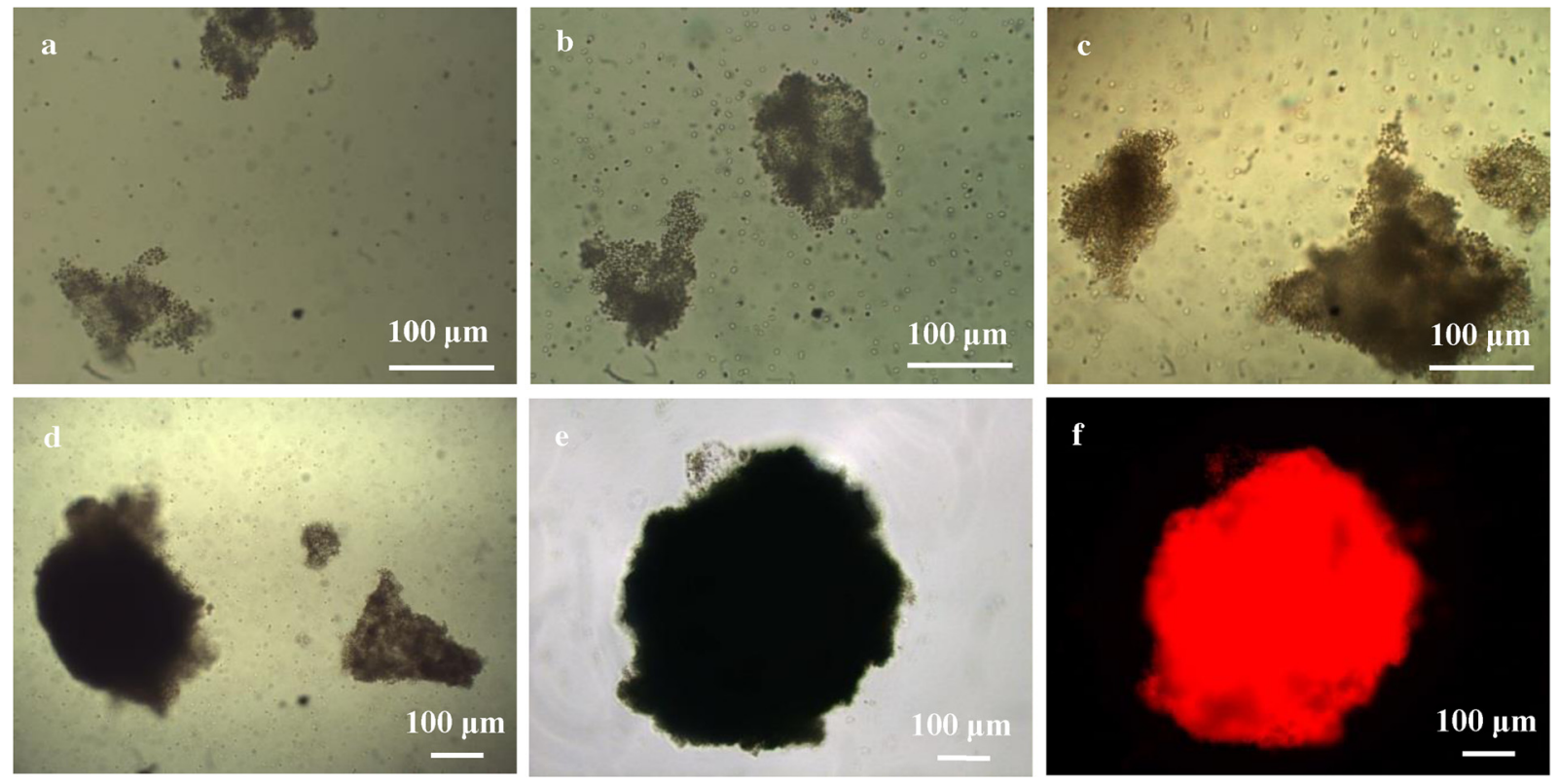

Fig. 8. Microphotographs of Microcystis colonies cultured in medium with $100 \mathrm{mg} \mathrm{L}^{-1} \mathrm{Ca}^{2+}$ at different times. Panels (a), (b), (c), (d), and (e) show days 12, 24, 36, 54, and 72, respectively. (f) Fluorescence micrograph on day 72. 

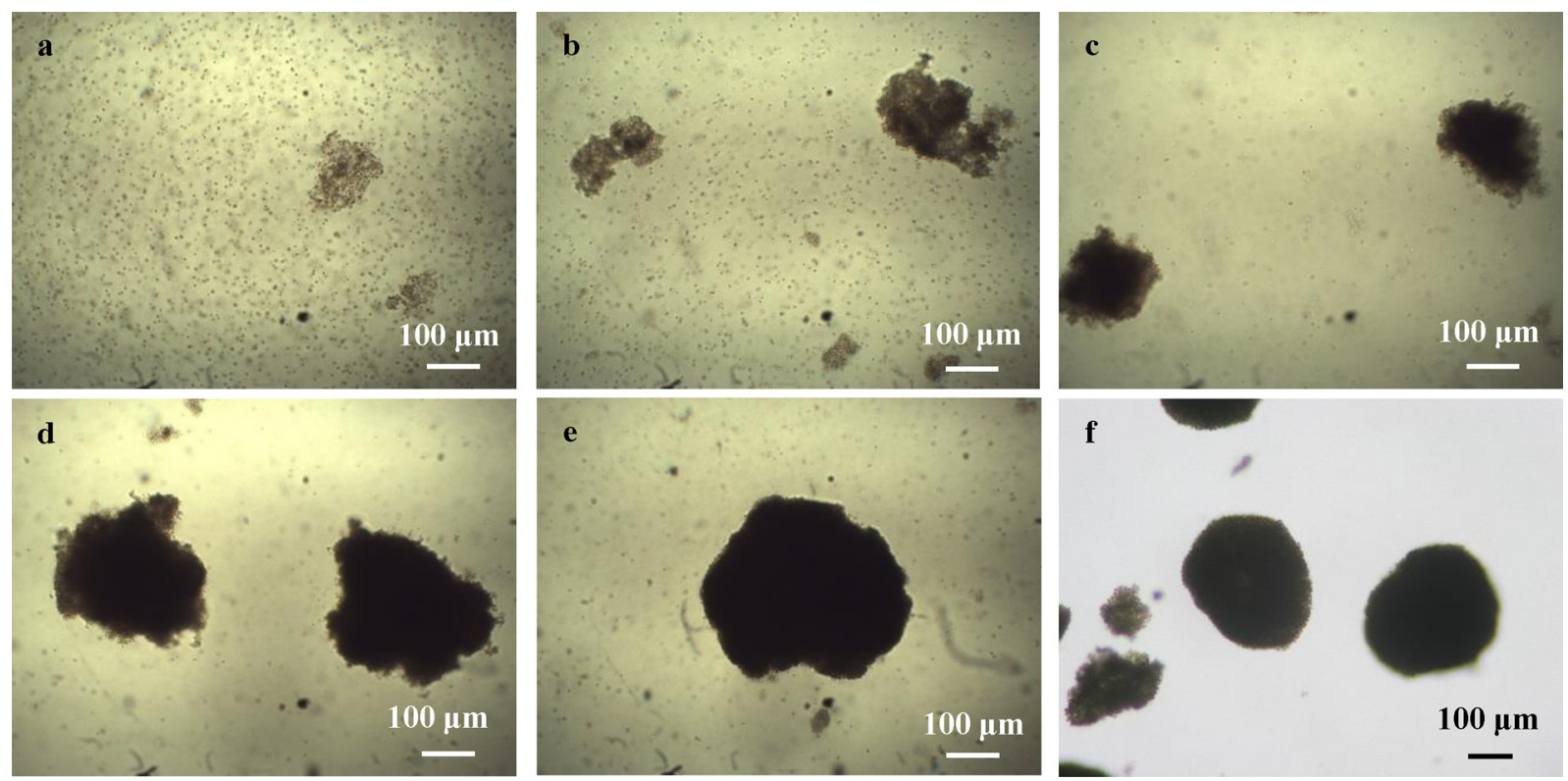

Fig. 9. Microphotographs of Microcystis colonies grown in medium under different $\mathrm{Ca}^{2+}$ concentrations on day 72 (a) $20 \mathrm{mg} \mathrm{L}^{-1}$; (b) $40 \mathrm{mg} \mathrm{L}^{-1}$; (c) $60 \mathrm{mg} \mathrm{L}{ }^{-1}$; (d) $80 \mathrm{mg} \mathrm{L}^{-1}$; (e) $100 \mathrm{mg} \mathrm{L}^{-1}$, and (f) collected from Lake Taihu in June 2016.

similar to those treated with the raw water of Lake Taihu. Thus, high $\mathrm{Ca}^{2+}$ concentrations play an important role in colony formation.

In addition, $\mathrm{Ca}^{2+}$ can rapidly cause aggregation of negatively charged algae derived organic matter due to bridging (Miao et al., 2016). Hence, a biological role for the excretion of fibrous exopolysaccharides (Harel et al., 2012) could be facilitation of cell adhesion in colonies. According to the f-CC/f-B proposed by Xiao et al. (2017), colony formation by cell-adhesion only dominated during the first 12 days of lab culture and then changed to cell-division due to the decrease in $\mathrm{Ca}^{2+}$ concentrations caused by precipitation/complexation. Moreover, the effect of cell adhesion is gradually masked as the colony size increases, a Microcystis colony containing enough cells could obviously increase in size by cell division as well. Lab results showed that a $\mathrm{Ca}^{2+}$ cross-linkage with a large number of Microcystis cells formed $80 \mu \mathrm{m}$ sized colonies within 12 days (Fig. 6). Inversely, if a colony was formed via cell division under measured mean growth rates of 0.15 day $^{-1}$ (Fig. 3) during 30 days, a single cell could divide into 90 cells, which would led to an approximately $39 \mu \mathrm{m}$ sized colony as calculated from an average Microcystis cell size (Reynolds and Jaworski, 1978). Therefore, compared to colony formation only by cell division, short-term complexation of $\mathrm{Ca}^{2+}$ with exopolysaccharides can greatly reduce the time required to form large Microcystis colonies.

In general, cell-division leads to colonies with regularly arranged cells, whereas the arrangement of cells in a colony formed by cell-adhesion is irregular (Xiao et al., 2018, 2017; Yang et al., 2008). Our experimental results show that Microcystis colony formation is dominated by cell-adhesion in the first 12 days (Fig. 6, Table 1), and therefore the colony morphology is sparse (Fig. 8a). This colony morphology is consistent with the morphology of Microcystis colonies cultured under high $\mathrm{Ca}^{2+}$ concentrations observed in other studies (An et al., 2017; Sato et al., 2017; Wang et al., 2011; Zhao et al., 2011), but it is very different from colonies observed in the wild (Xiao et al., 2018). To further verify the transition route from non-classical colonies to $M$. ichthyoblabe-like colonies, we extended the culture time to observe whether the initial colonies tend to grow larger and exhibit more tightly arranged cells. Excitingly, the colony morphologies in most of the $\mathrm{Ca}^{2+}$ treatments on day 72 were similar to those of $M$. ichthyoblabe present in Lake Taihu in June 2016, except for the treatment with $\mathrm{Ca}^{2+}$ concentration of $20 \mathrm{mg} \mathrm{L}^{-1}$ (Fig. 9). After 12 days, colony formation/ growth became dominated by cell-division (Table 1). Colony formation by cell division prevents the newly divided cells from separating from the mother cells by increasing the extracellular polysaccharide content (Kessel and Eloff, 1975; Yang and Kong, 2012). Our results show that non-classical colonies tend to grow larger (Fig. 6), and that there are more cells per unit area (Fig. 8), which suggests that the newly divided cells fill the gaps in the original colony formed by cell adhesion. Moreover, fluorescence micrography showed that the formed Microcystis colonies were composed of living single cells and did not contain other impurities (Fig. 9f). The M. ichthyoblabe-like colonies failed to form in treatments with $20 \mathrm{mg} \mathrm{L}^{-1} \mathrm{Ca}^{2+}$, maybe due to the fact that the level of exopolysaccharides was too low to prevent the divided cells from leaving the mother cells (Fig. 5a). Hence, colonies with a morphology similar to that of $M$. ichthyoblabe in the field could be induced in the laboratory, but it requires additional analyses to decipher if the field $M$. ichthyoblabe is a morphotype of $M$. aeruginosa. This needs to further verify the morphological transformation model of Microcystis colonies proposed by Xiao et al. (2018) that $M$. ichthyoblabe-like colonies could gradually change into $M$. wesenbergii-like colonies and, then, to $M$. aeruginosa-like colonies in future studies.

\subsection{The effect of increasing $\mathrm{Ca}^{2+}$ concentrations on Microcystis blooms}

Our laboratory results also showed that higher $\mathrm{Ca}^{2+}$ concentrations led to a larger colony size (Figs. 6 and 7). Lake Dianchi is divided into Caohai and Waihai by a causeway, and the mean $\mathrm{Ca}^{2+}$ concentrations in Caohai $\left(62.42 \mathrm{mg} \mathrm{L}^{-1}\right)$ was higher than that in Waihai $(27.13 \mathrm{mg}$ $\mathrm{L}^{-1}$ ) (Liu et al., 2009). Consistent with our results, about $80 \%$ of $\mathrm{Mi}$ crocystis biomass was contributed by colonies larger than $220 \mu \mathrm{m}$ in Caohai (Feng et al., 2019) but by colonies smaller than $200 \mu \mathrm{m}$ in Waihai (Wu et al., 2014) during summer. We also gathered the mean $\mathrm{Ca}^{2+}$ concentrations and the weighted mean colony size of Microcystis during summer from other lakes (Lake Huron (Chapra et al., 2012; Tang et al., 2014), Lake Erie (Rowe et al., 2016; Yuan, 2017), Lake Gull (Moss et al., 1980; White and Sarnelle, 2014), and Lake Erhai (Ao et al., 2014; Wang et al., 2018a)). The weighted mean colony size was calculated from the frequency distribution of different Microcystis colony sizes. However, some field studies only presented the biovolume proportion of different colony size groups. For instance, the biovolume proportions of $<100 \mu \mathrm{m}, 100-200 \mu \mathrm{m}, 200-300 \mu \mathrm{m}$ and $300-400 \mu \mathrm{m}$ were $27.3 \%, 63.7 \%, 7.9 \%$ and $1.1 \%$ in Aug 2016 of Lake Waihai (Wu 


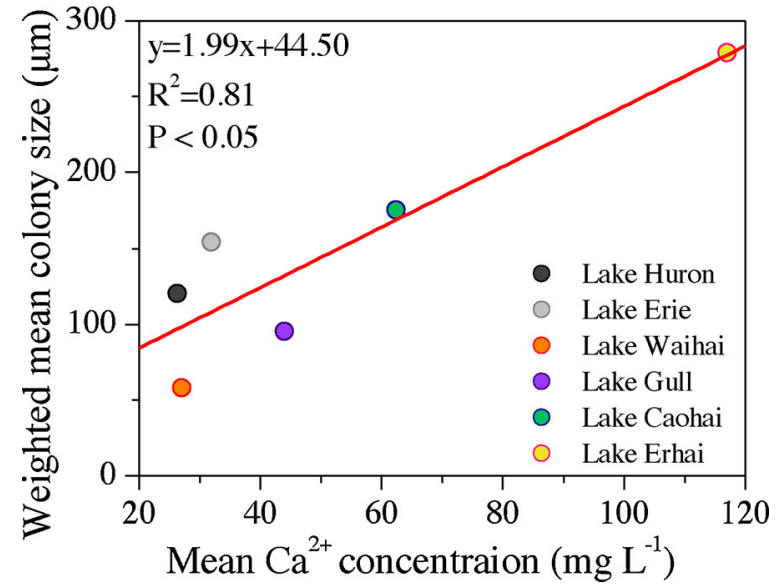

Fig. 10. Correlation between mean $\mathrm{Ca}^{2+}$ concentrations and weighted mean colony size of Microcystis based on published data.

et al., 2014), respectively. In this case, the median colony size in different group were set as $50 \mu \mathrm{m}, 150 \mu \mathrm{m}, 250 \mu \mathrm{m}$ and $350 \mu \mathrm{m}$, respectively, and used to calculated the number of cells per colony by Eq. (4) (Reynolds and Jaworski, 1978). We, then, determined the percent of different median colony sizes via dividing biovolume proportions by number of cells per median colony. Finally, the weighted mean colony size was calculated. A significant positive relationship was found between mean $\mathrm{Ca}^{2+}$ concentrations and weighted mean colony size based on the above field data (Fig. 10).

Microcystis bloom formation requires sufficient algal biomass, cellular buoyancy, and weak turbulence (Reynolds, 2006). Our laboratory results show that increasing $\mathrm{Ca}^{2+}$ concentrations slightly restrain biomass growth (Fig. 3), but higher $\mathrm{Ca}^{2+}$ concentrations led to more colonies (Fig. 7). Compared with single cells, a large colony has more ecological advantages, such as defence against zooplankton grazing, viral or bacterial attack, and other potential negative environmental factors (Cyr and Curtis, 1999; Wu and Kong, 2009; Yamamoto et al., 2011). Large colonies also enhance beneficial interactions with microbes and microzoopankton (Paerl and Millie, 1996). Protozoan grazing could consume single cells, but grazing on competitors also ensures adequate nutrient and metabolite exchange (Paerl, 1996).

High $\mathrm{Ca}^{2+}$ concentration did not influence the microcystin content (Fig. 5b), but it promoted bEPS content (Fig. 5a). Li et al. (2018) indicated that $M$. wesenbergii colonies have more bEPS than other $M i-$ crocystis colonies, and barely disaggregate under strong mixing conditions. Consequently, less biomass will be in the vulnerable grazing range (Burkert et al., 2001). All in all, conditions with high $\mathrm{Ca}^{2+}$ concentration will probably retain more biomass and larger colonies than those with low $\mathrm{Ca}^{2+}$. Hence, the Microcystis water bloom in Lake Taihu is not only affected by nutrient inputs, elevated air temperatures and declined wind speed (Deng et al., 2018, 2014; Zhang et al., 2018), but also may have been influenced by the increase in $\mathrm{Ca}^{2+}$ concentrations from 16 to $44.8 \mathrm{mg} \mathrm{L}^{-1}$ during the last 60 years (Tao et al., 2013).

\section{Conclusions}

(1) $\mathrm{Ca}^{2+}$ causes Microcystis to rapidly aggregate and form a colony through cell adhesion, then, colony formation by cell division dominates due to the reduction of $\mathrm{Ca}^{2+}$ concentrations caused by precipitation/complexation.

(2) Although the initial colony morphology by cell adhesion is sparse, the newly divided cells subsequently constantly fill the gaps in the original colony in the treatments with a $\mathrm{Ca}^{2+}$ concentrations $>40$ $\mathrm{mg} \mathrm{L}^{-1}$, which, on day 72 , creates a colony with a similar morphology to that of $M$. ichthyoblabe colonies in Lake Taihu.
(3) Laboratory experiments show that increased concentrations of $\mathrm{Ca}^{2+}$ slightly reduced Microcystis growth rates but enhanced the colony proportion of total biovolume and colony size that help Microcystis survive in the field.

(4) Microcystin levels are not altered by $\mathrm{Ca}^{2+}$ concentrations.

\section{Declaration of Competing Interest}

The authors declare that they have no known competing financial interests or personal relationships that could have appeared to influence the work reported in this paper.

\section{Acknowledgements}

This work was supported by the Fundamental Research Funds for the Central Universities [2015B36214]. This research was also supported by the China Scholarship Council for Huaimin's study in Wageningen University. Prof. Hans W. Paerl is cordially thanked for providing valuable comments on the manuscript. Wendy Beekman, Frits Gillissen, Marlies Vollebregt and Maíra Mucci are acknowledged for their help in the Wageningen University experiment, and Diandian $\mathrm{Xu}$ at Hohai University for providing language assistance.[CG]

\section{References}

Afoakwa, E.O., Paterson, A., Fowler, M., 2008. Effects of particle size distribution and composition on rheological properties of dark chocolate. Eur. Food Res. Technol. 226 (6), 1259-1268.

Ahn, W.-Y., Kalinichev, A.G., Clark, M.M., 2008. Effects of background cations on the fouling of polyethersulfone membranes by natural organic matter: experimental and molecular modeling study. J. Memb. Sci. 309 (1), 128-140.

Allen, M.M., 1968. Simple conditions for growth of unicellular blue-green algae on plates. J. Phycol. 4 (1), 1-4.

An, Q., Li, X., Wang, S., Huang, X., Jiang, Y., 2017. Effects of environmental factors on Microcystis aeruginosa colony formation and morphological characteristics in Three Gorges Reservoir. J. Lake Sci. 29 (2), 378-388.

Ao, H., Wu, C., Xiong, X., Jing, L., Huang, X., Zhang, K., Liu, J., 2014. Water and sediment quality in Qinghai Lake, China: a revisit after half a century. Environ. Monit. Assess. 186 (4), 2121-2133.

Bazin, H., Descotes, G., Bouchu, A., Petit-Ramel, M., 1995. Comparison of calcium complexation of some carboxylic acids derived from Dglucose and D-fructose. Can. J. Chem. 73 (8), 1338-1347.

Becker, D.W., Brand, J.J., 1982. An in vivo requirement for calcium in Photosystem II of Anacystis nidulans. Biochem. Biophys. Res. Commun. 109 (4), 1134-1139.

Bolch, C.J., Blackburn, S.I., 1996. Isolation and purification of Australian isolates of the toxic cyanobacteriumMicrocystis aeruginosa Kütz. J. Appl. Phycol. 8 (1), 5-13.

Burkert, U., Hyenstrand, P., Drakare, S., Blomqvist, P., 2001. Effects of the mixotrophic flagellate Ochromonas sp. On colony formation in Microcystis aeruginosa. Aquatic Ecol. 35 (1), 11-17.

Chapra, S.C., Dove, A., Warren, G.J., 2012. Long-term trends of Great Lakes major ion chemistry. J. Great Lakes Res. 38 (3), 550-560.

Chen, Y., Wang, L., Liang, T., Xiao, J., Li, J., Wei, H., Dong, L., 2018. Major ion and dissolved heavy metal geochemistry, distribution, and relationship in the overlying water of Dongting Lake, China. Environ. Geochem. Health.

Cyr, H., Curtis, J.M., 1999. Zooplankton community size structure and taxonomic composition affects size-selective grazing in natural communities. Oecologia 118 (3), 306-315.

de Figueiredo, D.R., Azeiteiro, U.M., Esteves, S.M., Goncalves, F.J., Pereira, M.J., 2004. Microcystin-producing blooms-a serious global public health issue. Ecotoxicol. Environ. Saf. 59 (2), 151-163.

Deng, J.M., Qin, B.Q., Paerl, H.W., Zhang, Y.L., Wu, P., Ma, J.R., Chen, Y.W., 2014. Effects of Nutrients, Temperature and Their Interactions on Spring Phytoplankton Community Succession in Lake Taihu, China. PLoS One 9 (12).

Deng, J.M., Paerl, H.W., Qin, B.Q., Zhang, Y.L., Zhu, G.W., Jeppesen, E., Cai, Y.J., Xu, H., 2018. Climatically-modulated decline in wind speed may strongly affect eutrophication in shallow lakes. Sci. Total Environ. 645, 1361-1370.

Duan, Z., Tan, X., Parajuli, K., Upadhyay, S., Zhang, D., Shu, X., Liu, Q., 2018. Colony formation in two Microcystis morphotypes: effects of temperature and nutrient availability. Harmful Algae 72, 14-24.

Dubois, M., Gilles, K.A., Hamilton, J.K., Rebers, P.T., Smith, F., 1956. Colorimetric method for determination of sugars and related substances. Anal. Chem. 28 (3), 350-356.

Feng, B., Wang, C., Wu, X., Tian, C., Zhang, M., Tian, Y., Xiao, B., 2019. Spatiotemporal dynamics of cell abundance, colony size and intracellular toxin concentrations of pelagic and benthic Microcystis in Lake Caohai, China. J. Environ. Sci. China (China) 84, 184-196.

Fujiki, T., Taguchi, S., 2002. Variability in chlorophyll $a$ specific absorption coefficient in marine phytoplankton as a function of cell size and irradiance. J. Plankton Res. 24 
(9), 859-874.

Gaury, P.K., Meena, N.K., Mahajan, A.K., 2018. Hydrochemistry and water quality of Rewalsar Lake of Lesser Himalaya, Himachal Pradesh, India. Environ. Monit. Assess. 190 (2).

Hadas, O., Kaplan, A., Sukenik, A., 2015. Long-term changes in cyanobacteria populations in lake kinneret (sea of galilee), Israel: an eco-physiological outlook. Life (Basel, Switzerland) 5 (1), 418-431.

Harel, M., Weiss, G., Daniel, E., Wilenz, A., Hadas, O., Sukenik, A., Sedmak, B., Dittmann, E., Braun, S., Kaplan, A., 2012. Casting a net: fibres produced by Microcystis sp in field and laboratory populations. Environ. Microbiol. Rep. 4 (3), 342-349.

Jansson, C., Northen, T., 2010. Calcifying cyanobacteria-the potential of biomineralization for carbon capture and storage. Curr. Opin. Biotechnol. 21 (3), 365-371.

Jindal, R., Thakur, R.K., Singh, U.B., Ahluwalia, A.S., 2014. Phytoplankton dynamics and species diversity in a shallow eutrophic, natural mid-altitude lake in Himachal Pradesh (India): role of physicochemical factors. Chem. Ecol. 30 (4), 328-338.

Joung, S.-H., Kim, C.-J., Ahn, C.-Y., Jang, K.-Y., Boo, S.M., Oh, H.-M., 2006. Simple method for a cell count of the colonial cyanobacterium, Microcystis sp. J. Microbiol. 44 (5), 562-565.

Katz, A., Nishri, A., 2013. Calcium, magnesium and strontium cycling in stratified, hardwater lakes: Lake Kinneret (Sea of Galilee), Israel. Geochim. Cosmochim. Acta 105, 372-394.

Kessel, M., Eloff, J.N., 1975. The ultrastructure and development of the colonial sheath of Microcystis marginata. Arch. Microbiol. 106 (3), 209-214.

Krivtsov, V., Bellinger, E.G., Sigee, D.C., 2005. Elemental composition of Microcystis aeruginosa under conditions of lake nutrient depletion. Aquatic Ecol. 39 (2) 123-134.

Kromkamp, J., Walsby, A.E., 1990. A computer model of buoyancy and vertical migration in cyanobacteria. J. Plankton Res. 12 (1), 161-183.

Li, M., Zhu, W., Gao, L., Lu, L., 2013a. Changes in extracellular polysaccharide content and morphology of Microcystis aeruginosa at different specific growth rates. J. Appl. Phycol. 25 (4), 1023-1030.

Li, M., Zhu, W., Sun, Q., 2013b. Solubilisation of mucilage induces changes inMicrocystiscolonial morphology. N. Z. J. Mar. Freshwater Res. 48 (1), 38-47.

Li, M., Zhu, W., Gao, L., 2014. Analysis of cell concentration, volume concentration, and colony size of Microcystis via laser particle analyzer. Environ. Manage. 53 (5), 947-958.

Li, M., Zhu, W., Guo, L., Hu, J., Chen, H., Xiao, M., 2016. To increase size or decrease density? Different Microcystis species has different choice to form blooms. Sci. Rep. 6, 37056.

Li, X., Luo, K., Ren, J., Wang, X., Mu, Q., Fan, W., 2017. Characterisation of extracellular polymeric substances from different cyanobacterial species and their influence on biocalcification processes. Environ. Chem. 14 (4), 254.

Li, M., Xiao, M., Zhang, P., Hamilton, D.P., 2018. Morphospecies-dependent disaggregation of colonies of the cyanobacterium Microcystis under high turbulent mixing. Water Res. 141, 340-348.

Liu, Z., Liu, X., He, B., Nie, J., Peng, J., Zhao, L., 2009. Spatio-temporal change of water chemical elements in Lake Dianchi, China. Water Environ. J. 23 (3), 235-244.

Lurling, M., van Oosterhout, F., Faassen, E., 2017. Eutrophication and warming boost cyanobacterial biomass and microcystins. Toxins 9 (2).

Lürling, M., Van Donk, E., 1997. Morphological changes in Scenedesmus induced by infochemicals released in situ from zooplankton grazers. Limnol. Oceanogr. 42 (4), 783-788.

Miao, L., Wang, C., Hou, J., Wang, P., Ao, Y., Li, Y., Lv, B., Yang, Y., You, G., Xu, Y., 2016. Effect of alginate on the aggregation kinetics of copper oxide nanoparticles (CuO NPs): bridging interaction and hetero-aggregation induced by $\mathrm{Ca} 2+$. Environ. Sci. Pollut. Res. - Int. 23 (12), 11611-11619.

Milne, C.J., Kinniburgh, D.G., van Riemsdijk, W.H., Tipping, E., 2003. Generic NICADonnan model parameters for metal-ion binding by humic substances. Environ. Sci. Technol. 37 (5), 958-971.

Moss, B., Wetzel, R., Lauff, G., 1980. Annual productivity and phytoplankton changes between 1969 and 1974 in Gull Lake, Michigan. Freshw. Biol. 10 (2), 113-121.

Nakamura, T., Adachi, Y., Suzuki, M., 1993. Flotation and sedimentation of a single Microcystis floc collected from surface bloom. Water Res. 27 (6), 979-983.

Paerl, H.W., 1996. Microscale physiological and ecological studies of aquatic cyanobacteria:macroscale implications. Microsc. Res. Tech. 33 (1), 47-72.

Paerl, H., Millie, D., 1996. Physiological ecology of toxic cyanobacteria. Phycologia 35, $160-167$.

Paerl, H.W., Otten, T.G., 2013. Harmful cyanobacterial blooms: causes, consequences, and controls. Microb. Ecol. 65 (4), 995-1010.

Qin, B., Yang, G., Ma, J., Wu, T., Li, W., Liu, L., Deng, J., Zhou, J., 2018. Spatiotemporal Changes of Cyanobacterial Bloom in Large Shallow Eutrophic Lake Taihu, China. Front. Microbiol. 9, 451.

Reynolds, C.S., 2006. The Ecology of Phytoplankton. Cambridge University Press.

Reynolds, C., Jaworski, G., 1978. Enumeration of natural Microcystis populations. Br. Phycol. J. 13 (3), 269-277.

Reynolds, C.S., Jaworski, G., Cmiech, H., Leedale, G., 1981. On the annual cycle of the blue-green alga Microcystis aeruginosa Kütz. emend. Elenkin. Philosophical Transactions of the Royal Society of London. B, Biological Sciences 293 (1068), 419-477.

Riding, R., 2006. Cyanobacterial calcification, carbon dioxide concentrating mechanisms, and Proterozoic?CAmbrian changes in atmospheric composition. Geobiology 4 (4), 299-316.

Rowe, M., Anderson, E., Wynne, T., Stumpf, R., Fanslow, D., Kijanka, K., Vanderploeg, H., Strickler, J., Davis, T., 2016. Vertical distribution of buoyant Microcystis blooms in a Lagrangian particle tracking model for short-term forecasts in Lake Erie. J. Geophys. Res. Oceans 121 (7), 5296-5314.

Sato, M., Amano, Y., Machida, M., Imazeki, F., 2016. Colony formation of highly dispersed Microcystis aeruginosa by controlling extracellular polysaccharides and calcium ion concentrations in aquatic solution. Limnology 18 (1), 111-119.

Sato, M., Omori, K., Datta, T., Amano, Y., Machida, M., 2017. Influence of extracellular polysaccharides and calcium ion on colony formation of unicellular Microcystis aeruginosa. Environ. Eng. Sci. 34 (3), 149-157.

Stanier, R., Kunisawa, R., Mandel, M., Cohen-Bazire, G., 1971. Purification and properties of unicellular blue-green algae (order Chroococcales). Bacteriol. Rev. 35 (2), 171.

Tang, H., Vanderploeg, H.A., Johengen, T.H., Liebig, J.R., 2014. Quagga mussel (Dreissena rostriformis bugensis) selective feeding of phytoplankton in Saginaw Bay. J. Great Lakes Res. 40, 83-94.

Tao, Y., Yuan, Z., Fengchang, W., Wei, M., 2013. Six-decade change in water chemistry of large freshwater Lake Taihu, China. Environ. Sci. Technol. 47 (16), 9093-9101.

Verweij, W., 2019. CHEAQS Next - Chemical Equilibria in AQuatic Systems, Version P2019.2. http://www.cheaqs.eu/.

Wang, Y.W., Zhao, J., Li, J.H., Li, S.S., Zhang, L.H., Wu, M., 2011. Effects of calcium levels on colonial aggregation and buoyancy of Microcystis aeruginosa. Curr. Microbiol. 62 (2), 679-683.

Wang, C., Hou, Z., Chu, Z., Wang, P., Cao, J., Yang, Y., 2018a. Vertical distribution of Microcystis and its influence factors in Lake Erhai during high risk period for algal bloom. Research of Environmental Sciences 31 (7), 1250-1257.

Wang, M., Wang, J., Wang, Q., Yang, C., Zou, Z., Qian, B., 2018b. Characteristics of plankton community structure and eutrophication status in Dongting Lake in the season with normal water level. Chinese Journal of Ecology 37 (8), 2418-2429.

White, J.D., Sarnelle, O., 2014. Size-structured vulnerability of the colonial cyanobacterium,Microcystis aeruginosa,to grazing by zebra mussels (Dreissena polymorpha). Freshw. Biol. 59 (3), 514-525.

Wilcox, D., Dove, B., McDavid, D., Greer, D., 2002. UTHSCSA Image Tool for Windows Version 3.0. The University of Texas Health Science Center, San Antonio, Texas.

Wu, X., Kong, F., 2009. Effects of light and wind speed on the vertical distribution of Microcystis aeruginosa colonies of different sizes during a summer bloom. Int. Rev. Hydrobiol. 94 (3), 258-266.

Wu, X., Kong, F., Zhang, M., 2011. Photoinhibition of colonial and unicellular Microcystis cells in a summer bloom in Lake Taihu. Limnology 12 (1), 55-61.

Wu, Y., Li, L., Gan, N., Zheng, L., Ma, H., Shan, K., Liu, J., Xiao, B., Song, L., 2014. Seasonal dynamics of water bloom-forming Microcystis morphospecies and the associated extracellular microcystin concentrations in large, shallow, eutrophic Dianchi Lake. J. Environ. Sci. (China) 26 (9), 1921-1929.

Xiao, M., Willis, A., Burford, M.A., Li, M., 2017. Review: a meta-analysis comparing celldivision and cell-adhesion in Microcystis colony formation. Harmful Algae 67, 85-91.

Xiao, M., Li, M., Reynolds, C.S., 2018. Colony formation in the cyanobacterium Microcystis. Biol. Rev. Camb. Philos. Soc. 93 (3), 1399-1420.

Xu, H., Yan, Z., Cai, H., Yu, G., Yang, L., Jiang, H., 2013. Heterogeneity in metal binding by individual fluorescent components in a eutrophic algae-rich lake. Ecotoxicol. Environ. Saf. 98, 266-272.

Xu, H., Lv, H., Liu, X., Wang, P., Jiang, H., 2016. Electrolyte cations binding with extracellular polymeric substances enhanced Microcystis aggregation: implication for Microcystis bloom formation in eutrophic freshwater lakes. Environ. Sci. Technol. 50 (17), 9034-9043.

Yamamoto, Y., Shiah, F.-K., Chen, Y.-L., 2011. Importance of large colony formation in bloom-forming cyanobacteria to dominate in eutrophic ponds. Ann. Limnol. - Int. J. Limnol. 47 (2), 167-173.

Yang, Z., Kong, F., 2012. Formation of large colonies: a defense mechanism of Microcystis aeruginosa under continuous grazing pressure by flagellate Ochromonas sp. J. Limnol. 71 (1), 5.

Yang, Z., Kong, F., Shi, X., Cao, H., 2006. Morphological response of Microcystis aeruginosa to grazing by different sorts of zooplankton. Hydrobiologia 563 (1), 225-230.

Yang, Z., Kong, F., Shi, X., Zhang, M., Xing, P., Cao, H., 2008. Changes in the morphology and polysaccharide content of Microcystis aeruginosa (Cyanobacteria) during flagellate grazing(1). J. Phycol. 44 (3), 716-720.

Yang, Z., Kong, F.X., Cao, H.S., Shi, X.L., 2009. Observation on colony formation of Microcystis aeruginosa induced by filtered lake water under laboratory conditions. Ann. Limnol. - Int. J. Limnol. 41 (3), 169-173.

Yuan, F., 2017. A multi-element sediment record of hydrological and environmental changes from Lake Erie since 1800. J. Paleolimnol. 58 (1), 23-42.

Zhang, M., Shi, X., Yang, Z., Yu, Y., Shi, L., Qin, B., 2018. Long-term dynamics and drivers of phytoplankton biomass in eutrophic Lake Taihu. Sci. Total Environ. 645, 876-886.

Zhao, L., Lu, L., Li, M., Xu, Z., Zhu, W., 2011. Effects of Ca and Mg levels on colony formation and EPS content of cultured M. Aeruginosa. Procedia Environ. Sci. 10, 1452-1458.

Zhu, W., Zhou, X., Chen, H., Gao, L., Xiao, M., Li, M., 2016. High nutrient concentration and temperature alleviated formation of large colonies of Microcystis: evidence from field investigations and laboratory experiments. Water Res. 101, 167-175. 